NBER WORKING PAPER SERIES

\title{
THE LABOR MARKET EFFECTS OF RISING HEALTH INSURANCE PREMIUMS
}

\author{
Katherine Baicker \\ Amitabh Chandra \\ Working Paper 11160 \\ http://www.nber.org/papers/w11160
NATIONAL BUREAU OF ECONOMIC RESEARCH
1050 Massachusetts Avenue
Cambridge, MA 02138
February 2005

This paper was prepared for Program Evaluation, Human Capital, and Labor Market Public Policy: A Research Conference in Honor of Mark C. Berger in Lexington, Kentucky on October 7-8th 2004. Mark was an extraordinary advisor, friend and mentor, and we will miss his advice, generosity, and insights. We are grateful to Mark Berger, Jon Gruber, Ellen Meara, Derek Neal, Douglas Staiger, conference participants at the Research Conference and the annual meetings of the American Economic Association, and especially Aaron Yelowitz for very insightful comments. We received funding from NIA-P01 AG19783-02. The opinions in this paper are those of the authors and should not be attributed to the NIA or NBER. The views expressed herein are those of the author(s) and do not necessarily reflect the views of the National Bureau of Economic Research.

(C) 2005 by Katherine Baicker and Amitabh Chandra. All rights reserved. Short sections of text, not to exceed two paragraphs, may be quoted without explicit permission provided that full credit, including $\odot$ notice, is given to the source. 
The Labor Market Effects of Rising Health Insurance Premiums

Katherine Baicker and Amitabh Chandra

NBER Working Paper No. 11160

February 2005

JEL No. I1, J0, J3

\begin{abstract}
Since 2000, premiums for employer-provided health insurance have increased by 59 percent with little corresponding increase in the generosity of coverage. The effect of this increase in costs on wages and employment will depend on workers' valuation of the benefit, the elasticities of labor supply and demand, and institutional constraints on employers' ability to lower wages. Measuring these effects is difficult, however, without a source of exogenous variation in the cost of benefits. We use variation in medical malpractice payments driven by the recent "medical malpractice crisis" to identify the causal effect of rising health insurance premiums on wages, employment, and health insurance coverage. We estimate that a 10 percent increase in health insurance premiums reduces the aggregate probability of being employed by 1.6 percent and hours worked by 1 percent, and increases the likelihood that a worker is employed only part-time by 1.9 percent. For workers covered by employer provided health insurance, this increase in premiums results in an offsetting decrease in wages of 2.3 percent. Thus, rising health insurance premiums may both increase the ranks of the unemployed and place an increasing burden on workers through decreased wages for workers with employer health insurance and decreased hours for workers moved from full time jobs with benefits to part time jobs without.
\end{abstract}

Katherine Baicker

Department of Economics

6106 Rockefeller Hall

Dartmouth College

Hanover, NH 03755

and NBER

kbaicker@dartmouth.edu

Amitabh Chandra

Department of Economics

6106 Rockefeller Hall

Dartmouth College

Hanover, NH 03755

and NBER

achandra@dartmouth.edu 


\section{INTRODUCTION}

In the United States, two-thirds of the non-elderly population is covered by employerprovided health insurance (EHI), either directly or as a dependent through a family member's coverage. ${ }^{1}$ According to a national survey conducted by the Kaiser Family Foundation, the cost of EHI has increased by over 59 percent since 2000 with no accompanying increase in the scale or scope of benefits; between 2003 and 2004 the price of premiums increased 11.2 percent, a nine percentage point increase over the 2.3 percent increase in workers' hourly earnings. ${ }^{2}$ Increases in health insurance premiums may have significant effects on labor markets, including changes in the number of jobs, hours worked per employee, wages, and compensation packages. Indeed, it is possible that a significant portion of the increase in the uninsured population may be a consequence of employers shedding this benefit as health-insurance premiums rise (Porter, 2004). Simple correlations are consistent with this mechanism: despite strong economic growth in the $1990 \mathrm{~s}$, the number of non-elderly uninsured grew by 3 percentage points to 15.7 percent of the population, while the price of health-insurance premiums grew by 34 percent.

Understanding how labor market characteristics affect adjustments to increased health insurance costs is of growing policy importance. Proposals to cover the uninsured often rely on "employer mandates" that would require employers to cover eligible workers. ${ }^{3}$ For example, California's Senate Bill 2 (also known as Proposition 72, narrowly defeated in November, 2004) would have required all employers with more than 20 employees to provide health insurance to their workers (who work more than 100 hours per month. Other policy proposals include the provision of tax credits for the purchase of non-group health insurance, differentially changing

\footnotetext{
${ }^{1}$ These tabulations are from the Annual Demographic Files of the Current Population Survey (CPS) for 1988-2003. We define the non-elderly population as those under the age of 65 .

${ }^{2}$ These figures are obtained from Kaiser Family Foundation (2003). In Figure 1 we use these data to illustrate the growth of premiums since 1996 for family and single-person policies.

${ }^{3}$ Yelowitz (2004) provides a thorough discussion of this legislation and estimates its economic impact.
} 
eligible employees' valuation of benefits provided by their employer versus wages.

The magnitude of the effects of increases in benefit costs on employment, wages, and health insurance coverage will be driven by the elasticities of labor supply and demand, institutional constraints on wages and compensation packages, and how much workers value the increase in health insurance costs. Since employers currently provide such coverage voluntarily, if workers fully value these benefits then they will bear the cost of the increase in reduced wages, with no accompanying change in employment, employment costs, or employee utility. ${ }^{4}$ In a world where workers value benefits at their cost and are able to sort between firms based on their preferences, and without other institutional constraints, increases in the costs of benefits should be fully offset by decreases in wages.

There are many reasons to believe that firms are limited in their ability to offset increases in the price of health insurance premiums through lower compensation. Institutional constraints (such as the minimum wage or IRS non-discriminatory provisions that limit the extent to which employers can offer differential benefits to their employees) limit a firm's ability to reduce compensation. For these reasons, increases in the cost of providing health insurance may not be neutral in terms of their effects on employment and the structure of work. However, identifying the magnitude of these effects is difficult. Data on premiums and wages are usually not jointly available at the individual level. Additionally, most micro-datasets (such as the SIPP and CPS) do not allow the researcher to control adequately for worker characteristics, such as ability, that might simultaneously influence the outcome under study. In this paper we uncover the causal

\footnotetext{
${ }^{4}$ This view is explicitly studied in the literature estimating the wage-fringe tradeoff. A $\$ 1$ increase in the value of fringes may offset by a $\$ 1$ reduction in fringe benefits - or, in the case of most tax-favored benefits, a $\$ 1 /(1-t)$ reduction, where $t$ is the tax rate. For example, Gruber (1994) demonstrates that the passage of the Pregnancy Discrimination Act in 1978 (that mandated that pregnancies no longer be treated as a "comparable illness") resulted in employers shifting the entire cost of the mandate onto employees.
} 
effect of increases in the cost of benefits on labor market outcomes by exploiting an exogenous source of variation in the cost of providing health insurance: the recent "medical malpractice crisis" where malpractice costs for physicians grew dramatically in some states but not in others. As we discuss in more detail below, the growth of malpractice payments affects both malpractice insurance premiums and the cost of health insurance: if the demand for health care is relatively inelastic (because of health insurance or public insurance programs), the increased cost of malpractice will be borne by consumers in the form of higher health insurance premiums, rather than primarily by physicians in the form of lower compensation (see Baicker and Chandra, 2005).

We use malpractice payments as an instrument for health insurance premiums in order to examine the effect of health insurance premiums on employment patterns, earnings, and health insurance coverage. We find that the cost of increases in health insurance premiums is borne by workers through decreased wages (for those with employer health insurance) and by decreased hours for those moved from full time jobs with benefits to part time jobs without. These results have strong implications for the distributional impact of many different health care reform proposals.

In Section II we outline a conceptual framework for our analysis. Section III examines econometric challenges to estimating the hypothesized effects that we predict and provides a justification for our use of malpractice payments as an instrumental variable for health premiums. In Section IV we describe the data that use. In an appendix we discuss in more detail several features of the National Practitioner Data Bank (NPDB), the dataset that we use to construct measures of the malpractice liability environment in each state and year. In Section V we present empirical results, including specification checks that provide validation for our use of 
malpractice payments as a plausible instrument for health insurance premiums. Finally, in Section VI we conclude with a discussion of the policy implications of our findings.

\section{CONCEPTUAL FRAMEWORK}

Summers (1989) examines the effects of mandated benefits (versus taxes) on wages and employment, highlighting the importance of the employees' valuation of the benefit. The provision of a benefit that is fully-valued by workers should not change employment - but should decrease wages by the cost of the benefit. Gruber and Krueger (1991) discuss this model more formally. In their framework, let $L_{d}=f(W+\alpha C)$ and $L_{s}=(W+C)$ be the labor demand and supply curves respectively. $W$ represents wages and $\alpha C$ represents employees' monetary valuation of health insurance. It is straightforward to demonstrate that:

$$
d W / d C=\left(\eta^{d}-\alpha \eta^{s}\right) /\left(\eta^{d}-\eta^{s}\right)
$$

where $\eta^{d}$ and $\eta^{s}$ are the price elasticities of labor demand and supply. If $\alpha=1$, then wages fall by the full cost of the mandated benefit, and if $\alpha=0$, then the results are identical to those obtained for the incidence of a payroll tax. Additionally, the proportional change in employment will be given by:

$$
d L / L=\eta^{d}\left(W_{0}-W_{1}-\Delta C\right) / W_{0}
$$

where $W_{0}$ and $W_{1}$ represent the initial and final levels of wages. Equation (2) demonstrates that the effect of rising health insurance costs on employment is inversely proportional to the wage offset caused by the employer provision of health insurance, and proportional to the elasticity of labor demand.

There are several reasons that wages may not respond to an increase in the price of a health benefit. First, depending on the magnitude of the $\alpha$ parameter, it is not clear how 
employees value an increase in health insurance costs if they are not accompanied by increases in the quality or quantity of benefits. If there has been an increase in benefit provision which substantially raises the costs of being uninsured (or, for that matter, a relative decrease in the utility of being covered in the non-group market), it is even possible that labor supply could increase to the point of raising total employment (formally, this would happen if $\alpha>1$ ). Additionally, workers may be myopic in their perceptions of the value of benefits - Gustman and Steinmeier (2001) note that survey respondents are often not even aware of the value of their pension and social-security benefits, and similar ignorance may characterize workers' valuation of health benefits. Second, workers may not be perfectly sorted between firms based on their preferences for benefits, and non-discrimination stipulations in the tax code limit the differentiation of benefit packages to full-time workers within the same firm. These nondiscrimination constraints create incentives to move workers between "covered" (with benefits) full time jobs and "uncovered" part time jobs. Third, the ability of firms to reduce wages for lower-skilled workers is restricted by the minimum wage. For this group (and broader groups subject to wage rigidities), increases in employers' costs of providing health insurance will result in employment reductions or in employers discontinuing health insurance benefits. For these three reasons, increases in the cost of health insurance could affect both total compensation and employment.

This model also does not capture an important dimension of potential employer responses to increased benefit costs: firms may offer benefits only to their full time employees, and an increase in the cost of a full time employee relative to a part time employee may induce firms to substitute towards part time workers. Note that such a substitution could result from benefits not being fully valued or from institutional constraints to differentially providing benefits or 
changing wages. This substitution towards part-time workers could result in a decrease in employer health insurance coverage and in hours worked, but an increase in employment, as measured by the number of employees. In contrast, if health insurance is viewed as a fixed cost per employee, increases in health insurance costs could cause firms to increase the hours of work per employee but reduce the number of employees. ${ }^{5}$ This effect ought to be concentrated in employees who work few hours, because it is precisely this group who would become more costly as a result of an increase in health insurance premiums. Employers may also find it attractive to move such workers to part-time positions without health insurance.

In light of these ambiguous analytical predictions on hours, employment, and the fraction of full time and part time jobs, assessing the labor market effects of increases in health insurance premiums is fundamentally an empirical question. ${ }^{6}$

\section{EMPIRICAL STRATEGY}

Evaluating the effect of rising health premiums on employment, wages, hours worked and the composition of employment (the share of jobs that are full time or part time) empirically is an exercise with numerous challenges. Datasets such as the Census and the CPS do not

\footnotetext{
${ }^{5}$ Cutler and Madrian (1998) develop such a model and find that when health insurance costs go up, the firm will find it advantageous to increase the hours of work per employee and reduce the number of employees. They find that increased health-insurance costs in the 1980 s led to a $3 \%$ increase in hours worked for those with EHI (and a decline in hours worked for those without EHI). However, in the Cutler-Madrian model it will cost the firm more in wages/benefits to encourage workers to supply more labor at the intensive margin. Thus, even with their highly stylized model, the net effect of an increase in the cost of benefits on both hours and employment is ambiguous: The firm will want to increase the hours worked by its employees if the marginal increase in compensation is less than the average hourly cost of providing benefits, but it will want to decrease hours worked and hire more workers in if the opposite is true. Because workers control the composition of the compensation package, the effect of increases in health insurance premiums on health insurance coverage will depend on whether workers fully value the health benefits.

${ }^{6}$ In an earlier version of this paper we included a formal model of the effect of health insurance premium increases on the labor market. As the above discussion notes, such a model is unable to generate unambiguous comparative statics and we have omitted it here.
} 
contain information on the employer costs of health insurance or the generosity of plans. Additionally, even if this information were available, such datasets do not allow the researcher to control adequately for worker characteristics that might also influence the outcome under study. ${ }^{7}$ In principle, a large-scale social experiment that does not suffer from attrition or agents attempting to compensate for their treatment regime may solve selection problems of this nature, and an instrumental variable estimation strategy can reproduce the experimental estimate if the underlying assumptions behind IV estimation are satisfied.

To motivate our analysis, consider the following structural equation for a worker $i$ in state $j$ and in year $t$ :

$$
\text { Outcome }_{i j t}=\beta_{0}+\beta_{1} H I_{i}+X_{i} \Pi+S_{j}+T_{t}+\varepsilon_{i j t}
$$

Here, Outcome $_{i}$ is the labor market outcome of interest (hours worked, wages, wage income, unemployment, part-time/full-time status, or receipt of health insurance). $X_{i}$ measures personlevel covariates including controls for family structure, marital status and industry. $S_{j}$ and $T_{t}$ are state and year fixed effects respectively, and $\varepsilon_{i j t}$ is a person-specific idiosyncratic term. ${ }^{8} H I_{i}$ measures the employer costs of providing individual $i$ with EHI. Technically, $H I_{i}$ should measure the difference between employer premiums and premiums for policies purchased in the nongroup market. We note that non-group health insurance (for individuals and families) appears to be priced nationally, so that controlling for individual characteristics accounts for variation in non-group prices. ${ }^{9}$ The above equation can be modified to include interaction effects and

\footnotetext{
${ }^{7}$ These limitations are identical to those that have plagued the literature on identifying the wage-fringe tradeoff. Currie and Madrian (2000) provide a comprehensive overview of this literature.

${ }^{8}$ Cutler and Madrian do not include state fixed effects. Yelowitz (1994) examines data from California; his analysis is therefore comparable to one where state fixed effects are included.

${ }^{9}$ Using data from www.eHealthInsurance.com, an online website that provides insurance quotes from many carriers, we note that there was less than a 5 percent difference in premiums across states like Arizona, California, Nebraska and Ohio. We priced premiums for a non-smoking family, comprising two parents (ages 35 and 37) and two children (ages 9 and 11). Each plan included an annual deductible of no
} 
indicator variables for certain demographic groups that may be of particular interest (for example, hourly workers, married women, workers near the minimum wage, or workers with EHI).

The first problem inherent in OLS estimation of (3) is that $\operatorname{cov}\left(\right.$ Cost of $\left.H I_{i} \varepsilon_{i}\right) \neq 0$. For example, workers with high ability may work at firms that offer generous health benefits, and, therefore, high premiums. Second, datasets such as the SIPP or CPS do not report the value or generosity of the health-insurance plan received by a worker. Empirical researchers have responded to this limitation by imputing health insurance premiums to each respondent based on industry (Cutler and Madrian, 1998) and based on industry, firm-size and family/single status (Yelowitz, 2004). These imputations solve the missing data problem and can in principle reduce the potential endogeneity problem. We first discuss the identification strategy implicit in this approach, and then contrast it with our alternative strategy.

Imputed premium data may be thought of as representing premiums that have been obtained using the match characteristics (such as industry and family structure) as instruments. That is, assuming that data on $H I_{i}$ was available, we could, in principle, estimate:

$$
H I_{d f s}=\gamma_{0}+\text { Industry }_{d}+\text { Firm Size }_{f}+\text { Family Structure }_{s}+v_{d f s}
$$

The $d f s$ subscripts make explicit the notion that (4) is estimated at the level of Industry $d$, Firm Size $f$, and Family Structure $s$ and not at the level of a person $i$. Equation (4) could also be

more than $\$ 2,000$ in addition to $20 \%$ coinsurance. Additionally, each plan had a maximum per-family out-of-pocket cost of between $\$ 4,000$ and $\$ 10,000$ per year.There are differences across states in what the policy covers (e.g. maternity benefits) and these differences do translate into higher premiums. However, the inclusion of state fixed-effects captures any residual variation in non-group premiums at the state level. We are grateful to Derek Neal for suggesting this clarification.

${ }^{11}$ In theory we could also use malpractice premiums as an instrument for health insurance premiums. However, there is no systematic source of malpractice insurance data. There is an annual survey conducted by the publication Medical Liability Monitor, but the survey does not rely on administrative data, does not cover all states or medical specialties, and varies year-to-year in the number of insurers who are surveyed. 
estimated at the state level. One could use the fitted values from (4) $\overline{H I}_{d f s}$ as the key regressor in the estimation of (3). Implicity, these fitted values may be thought of as characterizing the relationship:

$$
H I_{i} \equiv \overline{H I}_{d f s}+m_{i}
$$

Here, $m_{i}$ represents the portion of health-insurance premiums that are idiosyncratic to person $i$. Therefore, it is probably the case that $\operatorname{cov}\left(\varepsilon_{i j t}, m_{i}\right) \neq 0$ (that is, $m_{i}$ is determined by factors other than industry, firm-size and family structure). If the instruments are valid, then $\operatorname{cov}\left(\varepsilon_{i j t}, \overline{H I}_{d f s}\right)$ $=0$, and we may estimate:

$$
\text { Outcome }_{i j t}=\beta_{0}+\beta_{1} \overline{H I}_{d f s}+X_{i} \Pi+S_{j}+T_{t}+\varepsilon_{i j t}
$$

The central problem with estimating (6) in lieu of (3) is the possibility that $\operatorname{cov}\left(\overline{H I}_{d f s}, \varepsilon_{i}\right) \neq 0$. This would be true if the "instruments" (industry, firm-size, family structure) are correlated with $\varepsilon_{i}$, the unobservable characteristics of the worker. If workers in a certain sector of the economy, or those who are married, are systematically more likely to have different levels of unobservable characteristics that affect health insurance premiums, then such a correlation is possible. This problem is identical to the standard endogeneity problem in program evaluation, where receipt of the treatment is correlated with unobservable characteristics of the person receiving treatment.

A solution to this problem is to instrument for imputed premiums using variables that are uncorrelated with $\varepsilon_{i}$ and $m_{i}$ but are correlated with imputed health insurance premiums. In our analysis we use state level per-capita medical malpractice payments as an instrument for imputed premiums. For malpractice payments to provide a valid instrumental variable for imputed premiums, it must be the case that the instruments affect health premiums. Second, it should also 
be the case that malpractice payments are not correlated with unobservable characteristics of workers. In the next subsection, we explore the prima facia validity of these assumptions.

\section{The Medical Malpractice Crisis}

The "medical malpractice crisis" that began at the turn of the $21^{\text {st }}$ century refers to the dramatic increase in physician premiums for malpractice insurance. Baicker, Chandra and Fisher (2004), Chandra, Nundy and Seabury (2005), and Mello, Studdert, and Brennan (2003) provide an overview of this crisis and its underlying causes and consequences. Both the American Medical Association (AMA) and the Physician Insurers Association of America (PIAA) attribute the dramatic increase in physician malpractice insurance premiums to the growth in malpractice payments (see AMA (2004a, 2004b) and Smarr (2003)). Whereas other factors such as declines in insurers investment income - including the presence of an underwriting cycle, a less competitive insurance market, and climbing reinsurance rates - are acknowledged to have contributed to this medical malpractice crisis, insurer losses from increases in malpractice payments are believed to be the primary contributor to the growth of malpractice premiums. Indeed, a General Accounting Office (GAO) study of seven states concluded that the growth of insurer's losses from payments is the primary driver of the growth of premiums (see GAO, 2003a and 2003b).

If the demand for health services is inelastic, then the effect of increasing malpractice payments on malpractice premiums will have little effect on net physician compensation. Indeed, Baicker and Chandra (2005) argue that because of the nature of health insurance (which insulates the patient from the marginal costs of seeking care and which is subsidized by the tax code), the demand for medical services is relatively inelastic. The demand for health services by Medicare beneficiaries is likely to be even less elastic, as they are further insulated from even a 
wage-fringe benefit tradeoff. Consumers of health care are therefore likely to bear the brunt of the cost through increases in the price of health care (and, consequently, health insurance premiums). ${ }^{11}$ With this preliminary validation, we use increases in malpractice payments as an instrument for health insurance premiums to estimate the following first-stage equation:

$$
\overline{H I}_{i j t}=\gamma_{0}+\gamma_{1} \text { Malpractice Payments } s_{j t}+X_{i} \Pi+S_{j}+T_{t}+v_{i}
$$

where, as discussed below, malpractice payments are broken down by the size and number of payments for different specialties. Instrumenting for imputed premiums removes the bias from any residual correlation between $\varepsilon_{i}$ and $\overline{H I}_{i j t}$. This is because the instrument only picks up that part of the (within-state) variation in imputed premiums that is attributable to (within-state) changes in malpractice climate. It may be tempting to reason that the correlation of premiums with the instrument, malpractice payments, is potentially spurious because states with high malpractice payments may have workers who are systematically more or less abled. This is not the case, however, as all of our specifications include state fixed effects.

It is particularly important in the context of this source of variation to understand the way that workers will value benefits. Our use of this instrument does not rely on the fact that workers get more or better health care as their premiums rise. Rather, as malpractice costs rise, the price of purchasing health care through any source - employer insurance, non-group insurance, or out of pocket - will increase. Workers may be willing to accept lower wages in exchange for costlier health insurance because they would have to pay more on the open market for it, whether or not the increase in premiums is associated with higher value health care. 


\section{DATA}

\section{A. Health Insurance Premiums}

We use annual state-level data on health insurance premiums by type of policy (family or single) and employer size from the Kaiser Family Foundation/HRET survey for 1996 to 2002 (see Kaiser Family Foundation, 2003). ${ }^{12}$ We assign premiums to workers based on their state of residence and year. In most specifications we also match based on family structure (with single respondents given the single premium) and on firm size (with employees of small firms given the small firm premium, and unemployed respondents given the average premium) - although we also test the sensitivity of our results to potential changes in the composition of family size and employment.

In Figure 1 we illustrate the steady growth in premiums for family premiums and single premiums over the time-period of our study. All dollar figures are expressed in year 2001 dollars. Family premiums grew from an average of \$5,000 in 1996 to well over \$8,000 in 2002. Premiums for single policies also grew substantially—-from an economy-wide average of $\$ 2,000$ in 1996 to over $\$ 3,000$ in 2002 . In Figure 2 we illustrate the details of family and single policies for the 10 states with the largest population in 2000 - Panel A reports the level of premiums in 1996 and Panel B in 2002. We see that family premiums grew between 40 and 60 percent over this time period in these states. The growth in single person premiums was relatively smaller but still considerable: in states such as Florida, Georgia, Michigan and Ohio, premiums for single people grew by over 40 percent. Both panels also show the share of total premiums that were

\footnotetext{
${ }^{12}$ The Kaiser Family Foundation/Health Research and Educational Trust 2004 Annual Employer Health Benefits Survey (Kaiser/HRET) reports findings from a telephone survey of 1,925 randomly selected public and private employers. Firms range in size from small enterprises with a minimum of three workers to corporations with more than 300,000 employees. The Kaiser/HRET Employer Health Benefits Survey is based on previous surveys sponsored by the Health Insurance Association of America from 1986-1991 and Bearing Point (KPMG at the time of the surveys) from 1991-1998.
} 
paid for by employee and employer contributions-even though premiums increased substantially, the share paid by employees remained relatively stable.

\section{B. Labor Market Data}

The Current Population Survey (CPS) is a monthly survey of about 50,000 households conducted by the Bureau of the Census for the Bureau of Labor Statistics. The survey has been conducted for more than 50 years and is the primary source of information on the labor force characteristics of the U.S. civilian non-institutional population. The March (Annual Demographic Survey) files of the CPS contain information on hours worked, wage and salary income, unemployment, and health insurance coverage in the past year. In several years the February Dislocated Worker Supplement asked questions on health insurance eligibility and employer offering, in addition to actual coverage (for both dislocated and non-dislocated workers).

We use data from the 1996-2002 March CPS, supplemented with information from the 1997, 1999, and 2001 February survey. Because individuals are included in the CPS in two 4month cycles, our February samples include only three-quarters of the respondents from that year's March sample. We use information on demographics (such as age, gender, race, marital status, family size, and education), labor market variables (such as wage and salary, employment status, firm size, and hours worked), and health insurance coverage (such as source of coverage, and, from the February supplement, whether coverage was offered by the respondent's employer and whether the respondent was eligible). Because we expect premiums from last year to affect current labor market outcomes, we measure hours worked, full-time/part-time status and unemployment during the reference week of the survey (typically the second week of March). 
We include all respondents between the ages of 22 and 64, although we further limit the sample in some of our analyses. Our data are summarized in Table 1.

\section{Medical Malpractice Payments}

All malpractice payments made in the United States by or on behalf of a licensed health care provider must be reported to the National Practitioner Data Bank (NPDB) within 30 days under the Health Care Quality Improvement Act of 1986. Noncompliance is subject to civil penalties codified in 42 U.S.C. 11131-11152. We examine payments that resulted from either a court judgment against the provider or a settlement made outside of the courts. We use NPDB information on such payments for 1996-2002. ${ }^{13}$ We calculate the size and number of payments resulting from medical treatments (including diagnosis, medication, and other medical treatment), surgical treatments (including surgery and anesthesia), obstetrical treatment, and other treatments (including monitoring, equipment, intravenous and blood, and all others). Table 1 shows the growth of per-capita malpractice payments at the state level between 1996-99 and 2000-02. The variability of payments (over time within states) is the source of our identification. For example, over the 2001-03 period, per-capita payments were highest in the states of New York, Pennsylvania, New Jersey, Connecticut, West Virginia and Delaware. In these states the burden of malpractice liability was almost twice the US average of $\$ 13.5$ per person. See Chandra et al. (2005) for more details on the growth of malpractice payments as measured by the NPDB. We discuss potential limitations of the NPDB in the Appendix.

\footnotetext{
${ }^{13}$ We exclude payments that were linked to dentists, pharmacists, social workers or nurses. In a small fraction of payments, there are multiple physician defendants (and thus multiple reports) but only the total payment by all defendants is reported. In these cases we average the payment by the number of physicians involved. In the NPDB, 5 percent of payments are made by state funds in addition to other payments made by the primary insurer for the same incident. We match such payments based on an algorithm that uses unique physician identifiers, state of work, state of licensure, area of malpractice, type of payment (judgment or settlement) and year of occurrence.
} 
In some specifications we calculate malpractice payments per physician by obtaining data on state level physician counts using data from the 2003 Area Resource File (ARF) published by the National Center for Health Workforce Analysis. Data on the physician workforce by specialty and age are only available for 1989, 1995, 2000, and 2001. Intervening years are linearly interpolated.

\section{RESUlTS}

We begin with an examination of the effect of increases in health insurance premiums on employment, wages, and hours worked. The odd columns of Table 2 show the results of OLS estimation of equation (6). All regressions include state and year fixed effects and the individual-level controls outlined above, and are weighted using the March CPS final weights. Standard errors are clustered at the state level (clustering at the state-year level yields marginally smaller standard errors). Premiums, income, and hours are all measured in logs. The OLS effect of increases in health insurance premiums on wage and salary income, employment, and hours is small: a 10 percent increase in premiums leads to a 0.3 percent decrease in wage and salary income and a 0.04 percent increase in hours worked.

As discussed above, however, the OLS results are likely to be biased by omitted individual characteristics (such as ability) and economic conditions. We use medical malpractice payments (including real per capita dollars and the number of payments per capita, by specialty, current and lagged) to instrument for health insurance premiums. Similar results are obtained when payments are measured per doctor, rather than per capita. Table 3 reports first stage regressions for these instruments as in equation (5). For the two-stage least squares estimates that follow, we use the most flexible form of the instruments (which provides the greatest power 
in the first stage, with a joint F-statistic of 8.75), but here we show more constrained forms to aid in interpretation (since payments by different specialties are highly correlated). The results suggest that when per capita malpractice payments double, health insurance premiums increase by 1 to 2 percent. This is consistent with previous estimates that malpractice payments comprise around 1 percent of total health expenditures (Kessler and McClellan, 1996). We show the results of a similar regression at the state-year (rather than individual) level graphically in Figure 3.

Results from two-stage least squares estimation of equation (6) are shown in the even columns of Table 2 . Here we see a much bigger (although statistically insignificant) decrease in annual wage and salary income - a 10 percent increase in premiums reduces wages and salary by 1.3 percent. There is a large effect of premiums on usual hours worked - coming partly from increases in the probability of unemployment but also through increases in the probability of part time work. This is consistent with our expectation that as the cost of providing health insurance benefits increases, firms will substitute part time workers with limited benefits for full time workers with benefits. In fact, in our data only 22 percent of part time workers have employer health insurance, while 64 percent of full time workers do. Consistent with the reduction in fulltime jobs, there is also an overall decline in employment rates and a (statistically insignificant) decline in being covered by employer provided health insurance. In contrast to the OLS results, all the IV results are consistent with the predictions of a model where workers partially value health benefits or where firms are constrained in their ability to adjust wages.

As health insurance costs have risen, popular concern has grown over increases in required employee contributions to health insurance premiums. In fact, between 1996 and 2002, employee contributions to health insurance premiums remained relatively stable at just under 20 
percent. This fraction does not seem to respond to increases in health insurance premiums using our IV specification in column 12, the fraction of premiums paid by employees (and consequently employers) does not respond to increases in premiums. As shown in column 14, the dollar amount paid by employees and employers increases in the same proportion: We estimate that a 10 percent increase in premiums results in a 10 percent increase in both employer and employee contributions.

As previous models and empirical research have suggested, we might expect certain groups to be more sensitive in changes in the cost of health insurance. First, workers with health insurance should see a much bigger offset in their wages than workers without, who should see none. The first column of Table 4 tests this hypothesis by including the interaction of health insurance premiums and an indicator for coverage by employer health insurance. We see that, in fact, all of the reductions in income are borne by employees with health insurance. The magnitude of the elasticity of -0.23 is consistent with dollar-for-dollar offset (since premiums (paid with pre-tax dollars) are about 20 percent of wage and salary income at the mean) implying that covered workers bear the full incidence of increases in health insurance premiums. Similarly, as column (2) shows, part time workers see an increase in wages when health insurance premiums increase - consistent with workers moving from full time jobs with benefits to part time jobs with higher wages instead of benefits. These results also suggest that we should see differential effects of increases in premiums on employer health insurance coverage. The second panel of Table 4 explores this. Column (4) shows that part time workers are less likely to have employer health insurance as premiums increase, consistent with the results in column (2). If our theory's predictions are correct, we should also see declines in wages and salary income (and health insurance coverage from an employer) for workers in sectors where the demand for 
labor is particularly elastic. Because manufacturing goods are nationally traded and the labor demand for manufacturing workers is a derived demand, we would expect the local demand for such workers to be particularly sensitive to the price of health insurance. Columns (3) and (8) verify that this is indeed true. ${ }^{14}$

Which workers would be most likely to give up employer health insurance (in exchange for higher wages) as premiums increase? Married, healthy women are likely to have a lower value of employer health insurance, as they may have access to insurance though their husbands and lower utilization of health services. We construct an indicator variable for married women with self-reported health status of "excellent" or "very good." As column (5) shows, these women are indeed more likely to lose employer health insurance when premiums go up. Another group we might expect to be more likely to lose employer health insurance are workers facing institutional constraints - such as minimum wage workers whose wages cannot be lowered to accommodate increased benefits costs. As column (5) shows, workers who are paid hourly with a wage of less than $\$ 8 /$ hour are significantly more likely to lose health insurance as premiums increase.

Why do these groups "lose" health insurance? Do their employers stop offering health insurance (or do they move to jobs that don't offer insurance), or, alternatively, do they stop taking up health insurance that is offered to them, perhaps because of higher copays or employee premiums? While we have limited information on this front, we use the February CPS supplement to explore the change in employer health insurance offering when premiums increase. These results are reported in Table 5. Overall (column 1), there is little decrease in

\footnotetext{
${ }^{14}$ Employment in the manufacturing sector is measured as major industry of employment last year, while the dependent variable is measured as employment last week. (For this reason, we cannot include interactions with hours or employer health insurance, also measured currently as opposed to last year, using this dependent variable.)
} 
employer offering, but for hourly workers, a subgroup that we have identified as more likely to be affected by premium increases (column 2), we see more significant decline in employer offering as premiums increase. Here a 10 percent increase in premiums results in a 3.8 percentage point reduction in the probability of being offered health insurance coverage.

In Table 6 we explore the robustness of our identification strategy. We study the relationship between predicted heath-insurance premiums and variables that should not be predicted by our instruments. (The predicted premium captures the variation in our instruments that is used in the IV estimation.) Columns (1) to (5) of Table 6 demonstrate that the instruments are unable to predict variation in percent black, educational attainment, gender, marital status and health. Compositional changes in the levels of these variables could potentially affect the labor market outcomes that we study, but should not be affected by the increase in malpractice payments - and they are not. To further test our identification strategy, we also include as a dependent variable the probability that an employee is included in an employer pension plan, shown in column (6) of Table 6 . This could be viewed as a falsification test - health insurance premiums might not be expected to affect pension benefits - but it is possible that when health plan costs go up, all other forms of compensation (wages and other benefits) are reduced to absorb the cost. This does not seem to be the case: the probability of an employee having a pension benefit does not respond to increases in health insurance premiums in the IV specification, with an insignificant coefficient estimate of 0.12 (robust s.e. 0.12 ). Finally, in the last three columns, we note the lack of relationship between predicted premiums and health outcomes (measured at the state-year level). ${ }^{15}$ This finding rules out a class of explanations wherein the population of states with relatively higher malpractice payments is relatively

\footnotetext{
${ }^{15}$ Data on aggregate mortality come from the Area Resource File (reported at the county-year level, aggregated to the state-year level by the authors)
} 
sicker-and as sickness levels increase, health premiums rise. Population illness levels are not the driving factor here. Table 6 also notes that predicted premiums are not associated with higher cesarean-section rates (a procedure that is widely believed to be affected by the use of "defensive medicine"). ${ }^{16}$

We can use our estimates to study the economy-wide impact of the growth of healthinsurance premiums. Using the estimates in Tables 2 and 4, we can calculate the effect of rising health insurance premiums on the probability of being employed, employed as a full-time worker, average hours worked and annual income. These estimates are summarized in Table 7. A 20 percent increase in health insurance premiums (smaller than the increase seen in many areas in the last 3 years) would reduce the probability of being employed by 3 percentage points - the equivalent of approximately 4 million workers. A similar number of workers would move from full time jobs to part time, reducing the average number of hours worked per week by a little less than 1 hour. Annual (wage) income would be reduced by $\$ 2,000$ for those who are employed and have EHI. Together, these estimates demonstrate that the labor market effects of rising health insurance are far from neutral.

\section{CONCLUSION}

Rising health insurance premiums, unemployment, and uninsurance have led to increased scrutiny of the labor market consequences of rising benefits costs. These relationships are, however, difficult to disentangle without a source of exogenous variation. We use variation in

\footnotetext{
${ }^{16}$ Baicker and Chandra (2005) and Baicker, Fisher and Chandra (2004) demonstrate that increases in medical malpractice liability are not associated with changes in physician flows or the greater use of surgical procedures. This finding rules out a situation where increases in malpractice payments affect both the price and quantity of healthcare received by workers; changes in the malpractice climate appear to only affect the price of healthcare as measured by health insurance premiums.
} 
medical malpractice payments to derive the causal effect of rising health insurance premiums on wages, employment, and health insurance coverage.

We find that the cost of increasing health insurance premiums is borne primarily by workers in the form of decreased wages for workers with employer health insurance - so that they bear the full cost of the premium increase, but do not face labor market distortions. Our analysis implies that workers do at least partially value health insurance benefits, but that there are impediments to full adjustment through wages, particularly for certain groups. Nondiscrimination clauses that prevent firms from discontinuing coverage only for those workers who value it least mean that firms and workers have an incentive to move from full time jobs with benefits to part time jobs without as the costs of benefits rise. We see exactly this adjustment, with an increase in part time work (and increased wages and lower health insurance coverage rates for those workers). Workers who value coverage the least will have the greatest incentive to move into jobs that do not offer coverage as premiums rise. We find that groups that are likely to have low value of health insurance coverage through their employer, such as healthy married women, are more likely to lose coverage as premiums rise. Some workers, particularly low wage hourly workers whose wages cannot be reduced, may face even greater risk of becoming uninsured as the cost of health insurance increases.

Our results on wage-shifting are consistent with those in Gruber (1994): for workers with EHI, we observe full shifting of the increased price of health insurance onto wages. In addition, our results provide further evidence that the effects of increasing costs are borne disproportionately by particular groups. ${ }^{17}$ In contrast to Gruber's study and to the results in Gruber and Krueger (1991), we find effects on both hours and employment. These results may

\footnotetext{
${ }^{17}$ Gruber (1994) finds that the cost of the maternity benefits are fully borne by married women. Sheiner (1995) finds that demographic groups with higher ex ante insurance costs (such as older workers) experience full wage shifting when the price of health insurance increases.
} 
appear to be contradictory but they are not: in Gruber's study workers receive new maternity benefits and in Gruber and Krueger they receive more generous workers compensation. The fact that these studies find full shifting of increased costs to wages with no effect of the utilization of labor is thus consistent with the insights of Summers (1989) for the case of benefits that are valued by workers. In our paper, however, the increase in the price of health insurance premiums driven by the medical malpractice crisis did not change the generosity of health benefits. It is therefore unsurprising that workers do not value this increase in costs as highly, and that the labor market responds with decreased wages and labor utilization.

These results have strong implications for policies designed to cover the uninsured. For example, if employer health insurance mandates raise the cost of employing workers, we should expect most workers to bear the cost through reduced wages. If some classes of workers are exempt from the mandate (such as part time workers or those at particularly small firms), employers are likely to substitute uncovered jobs for covered ones, undermining the net effect of the mandate on insurance rates. More generally, rising health insurance premiums will place an increasing burden on workers and increase the ranks of both the uninsured and the unemployed. 


\section{APPENDIX 1: DISCUSSION OF THE NPDB}

The NPDB has been the subject of much criticism, from the PIAA in particular, and also from the GAO [GAO (2000) and Smarr (2003)]. One of the major points of criticism is the "corporate shield." This is a loophole that makes payments made on behalf of a hospital or other corporation exempt from inclusion in the NPDB, as long as any individual practitioner is dropped as part of a settlement agreement (see Hallinan (2004) for a recent commentary on this problem). We assess the potential importance of this source of bias by comparing jury verdicts reported in the NPDB to those from a proprietary data set compiled by the RAND Institute for Civil Justice based on the JVR (called the Jury Verdict Database, or JVDB) for New York and California. ${ }^{18}$ Between 1991 and 1999 the JVDB data showed an average annual growth of awards against physicians of 3.9\% in New York (and an average of 42 awards) and $4.3 \%$ in California (and an average of 35 awards), while the NPDB reported average annual growth of 13\% in New York (with an average of 53 awards) and 1.6\% in California (with an average of 43 awards). These results seem remarkably consistent, given the very different sampling frames. Nevertheless, we acknowledge that the corporate shield would result in some large payments not being reported to the databank. Even if this is true, it is not a source of bias - these omissions would only serve to weaken the estimated first-stage. A more problematic source of bias would occur if there is state-level variation in the magnitude of the corporate shield (a hypothesis on which there is no formal or anecdotal evidence). We include state-fixed effects in our analysis to help ameliorate this potential problem.

Despite its limitations, the NPDB is the most representative national and publicly available database on physician malpractice payments. Indeed, according to Hallinan (2004) hospitals rely on its existence to query the malpractice histories of potential hires; in 2002 the databank was queried 1.12 million times, or over 3,000 times a day.

\footnotetext{
${ }^{18}$ We are grateful to Aaron Yelowitz for recommending that that we explore the potential limitation of the NPDB in the context of the corporate shield. We are indebted to Seth Seabury at the RAND Institute for Civil Justice for facilitating this analysis.
} 


\section{REFERENCES}

American Medical Association. The Medical Liability Crisis: Talking Points., 2004a. (Accessed April 29th, 2004, at http://www.ama-assn.org/ama1/pub/upload/mm/399/mlr tp.pdf.)

American Medical Association. The Medical Liability Crisis: Why Repealing the McCarran-Ferguson or Passing Other Insurance Laws is Not the Answer. 2004b. (Accessed May 2nd, 2004, at http://www.ama-assn.org/ama1/pub/upload/mm/399/mlrcrisis.pdf.)

Baicker, Katherine, Elliott S. Fisher and Amitabh Chandra. "Malpractice Liability and the Practice of Defensive Medicine in the Medicare Program." Manuscript, December 2004. Department of Economics, Dartmouth College.

Baicker, Katherine and Amitabh Chandra. "The Effect of Medical Malpractice Liability on the Delivery of Health Care," in Alan Garber and David Cutler (Eds.) Frontiers of Health Policy, Vol 8, 2005 (Cambridge, MIT Press), forthcoming.

Chandra, Amitabh, Shantanu S. Nundy and Seth A. Seabury. "The Growth of Physician Malpractice Liability."Health Affairs 2005, forthcoming.

Currie, Janet and Brigitte C. Madrian. "Health, Health Insurance and the Labor Market," in Orley Ashenfelter and David Card (Eds.) The Handbook of Labor Economics Vol 3C, 2000. (Holland: Elseivier Science).

Cutler, David, and Brigitte Madrian. "Labor Market Responses to Rising Health Insurance Costs: Evidence on Hours Worked," RAND Journal of Economics, Vol 29, No. 3 (Autumn, 1998), 509530 .

Gruber, Jonathan, and Krueger, Alan.B. "The Incidence of Mandated Employer-Provided Insurance: Lessons from Workers' Compensation Insurance." In Bradford, D. (ed.) Tax Policy and the Economy 5, 1991, 111-43. Cambridge, Mass.: The MIT Press.

Gruber, Jonathan. “The Incidence of Mandated Maternity Benefits," American Economic Review, June 1994: 622-41.

Gustman, Alan L. and Thomas L. Steinmeier. "Imperfect Knowledge, Retirement and Saving." Manuscript, July 2001. Department of Economics, Dartmouth College.

Hallinan JT. Doctor Is Out: Attempt to Track Malpractice Cases Is Often Thwarted; Deleting a Physician's Name From a Suit Before Settling Keeps It Out of Data Bank; Dubbed the 'Corporate Shield'. Wall Street Journal. August 27, 2004: A1.

Kaiser Family Foundation, Kaiser Commission on Medicaid and the Uninsured. Health Insurance Coverage in America, 2002 Data Update, December 2003.

Kessler DP, McClellan MB. Do Doctors Practice Defensive Medicine? Quarterly Journal of Medicine. 1996 1996;111(2):353-390.

Mello MM, Studdert DM, Brennan TA. The new medical malpractice crisis. $N$ Engl $J$ Med. Jun 5 2003;348(23):2281-2284. 
National Center for Health Workforce Analysis, Department of Health and Human Services. Area Resource File; 2003.

Peterson MA, Priest GL. The Civil Jury: Trends in Trials and Verdicts, Cook County, Illinois, 19601979,. Santa Monica: RAND Corporation; 1982. R-2881-ICJ.

Porter, Eduardo, "Rising Cost of Health Benefits Cited as Factor in Slump of Jobs," New York Times, August 19, 2004.

Sheiner, Lousie. "Health Costs, Aging and Wages," Federal Reserve Board. Washing ton D.C.: 1995.

Sloan F, Bovbjerg RR, Githens PB. Insuring Medical Malpractice. New York, NY: Oxford University Press; 1991.

Smarr LE. Statement of the Physician Insurers Association of America before a joint hearing of the United States Senate Judiciary Committee and the Heath, Education, Labor and Pensions Committee. 2003. (Accessed May 2nd, 2004, at http://www.thepiaa.org/pdf_files/February 11_Testimony.pdf.)

Summers, Lawrence H. "Some Simple Economics of Mandated Benefits," American Economic Review, May 1989: 177-83.

United States. Department of Health and Human Services., Health Resources and Services Administration. Bureau of Health Professions., Division of Practitioner Data Banks. National Practitioner Data Bank Public Use Data File; 2004.

United States. General Accounting Office. Major Improvements are Needed to Enhance Data Bank's Reliability. Washington, D.C.; 2000.

United States. General Accounting Office. Medical Malpractice Insurance: Multiple factors have contributed to increased premium rates. Washington, D.C.: U.S. General Accounting Office; 2003a.

United States. General Accounting Office. Implications of Rising Premiums on Access to Health Care. Washington D.C.: U.S. General Accounting Office; 2003 b.

Yelowitz, Aaron. The Economic Impact of Proposition 72 on California Employers. Employment Policies Institute. Washington DC. September 2004. Available at www.EPIonline.org. Accessed on October $1^{\text {st }} 2004$. 


\section{FIGURE 1}

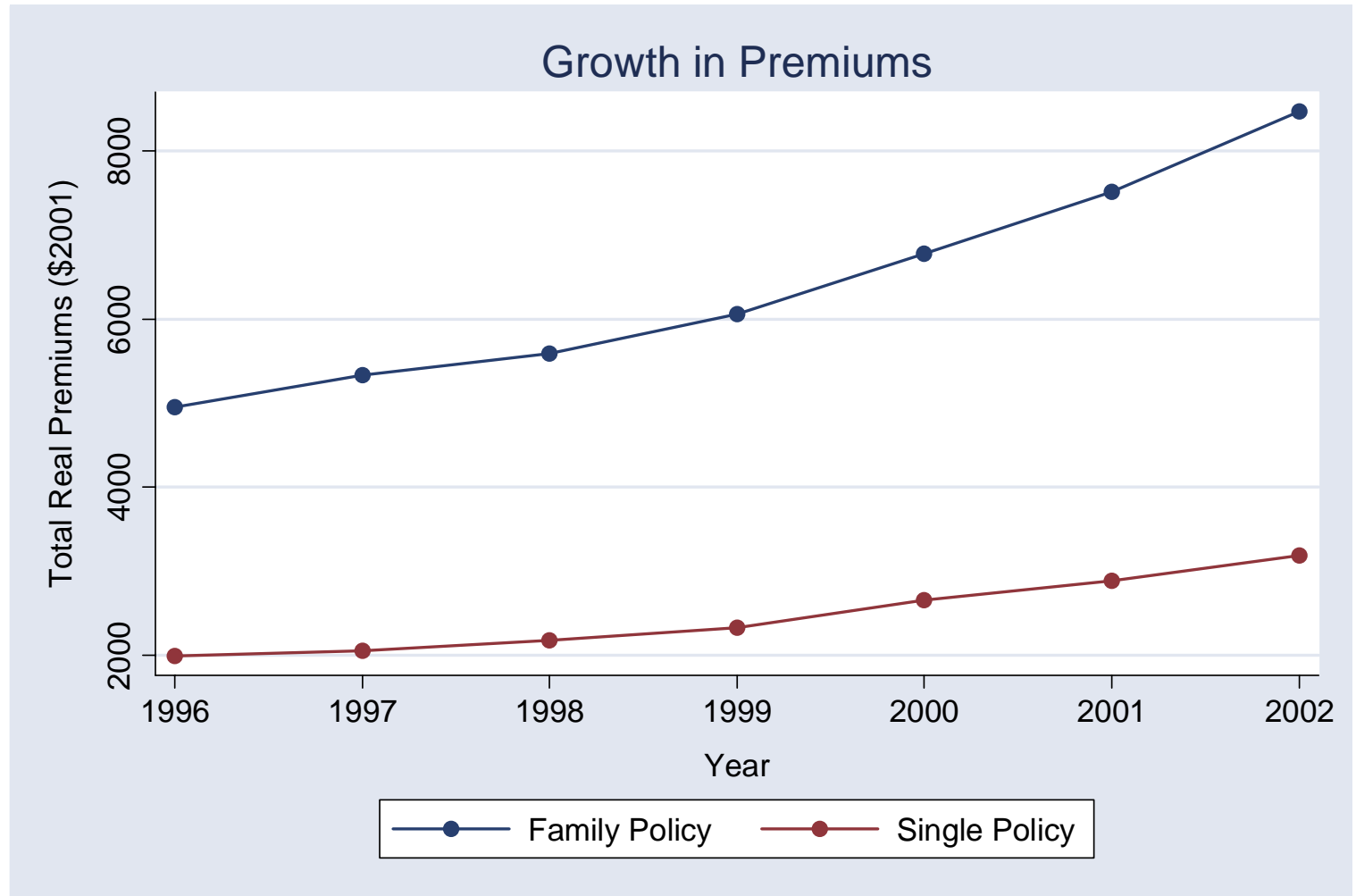

Notes:

Data from Kaiser Family Foundation/HRET survey. Premiums expressed in real year 2001 dollars. 


\section{FIGURE 2}

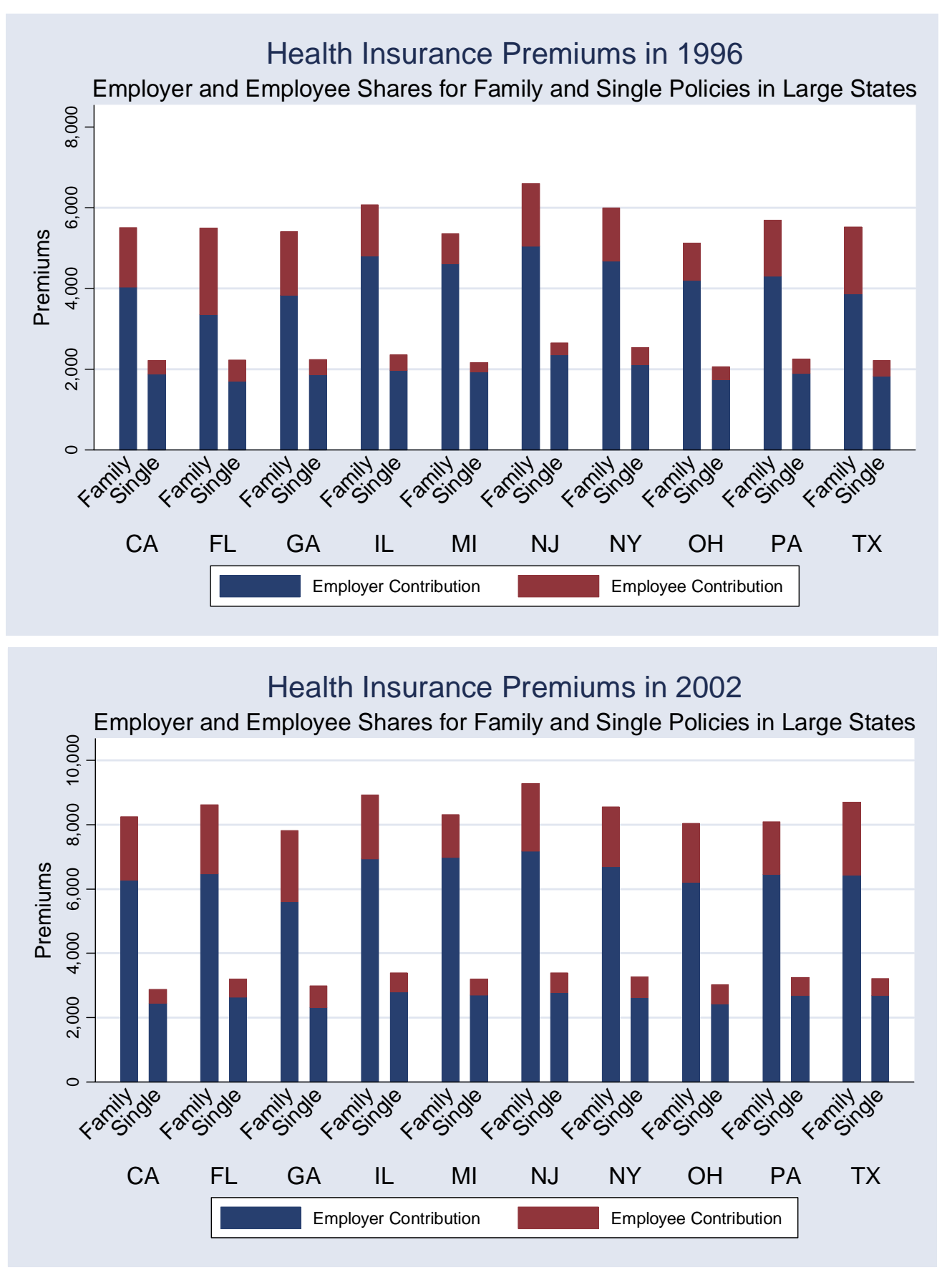

Notes:

Data from Kaiser Family Foundation/HRET survey. Premiums expressed in real year 2001 dollars. Ten largest states (by population) shown. 


\section{FIGURE 3}

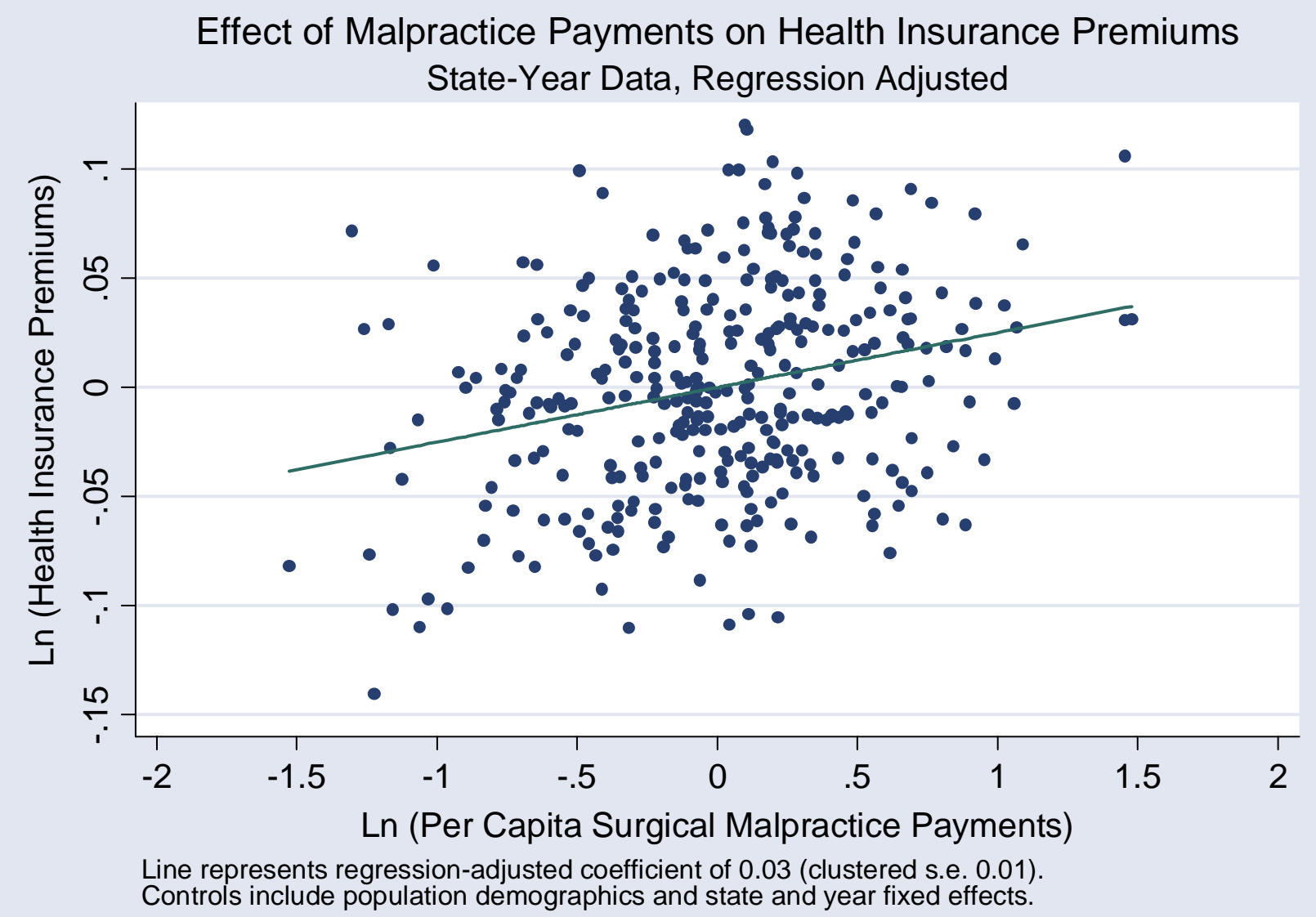

Notes:

Sample includes annual observations of 48 continental US states from 1996 to 2002.

Controls include categorical measures of educational attainment, race, age, marital status, health status, and gender mix (at the state-year level), as well as state and year fixed effects. Standard errors are clustered at the state level.

Malpractice payment data from National Practitioner Data Bank. Health insurance premium data from Kaiser Family Foundation/HRET survey. All dollars expressed in real year 2001 units. Covariates aggregated to state-year level from annual March CPS. 
Table 1: Summary Statistics

\begin{tabular}{|c|c|c|c|c|c|c|c|c|c|}
\hline & \multicolumn{3}{|c|}{ All } & \multicolumn{3}{|c|}{ 1996-1999 } & \multicolumn{3}{|c|}{ 2000-2002 } \\
\hline & Mean & Std Dev & Obs & Mean & Std Dev & Obs & Mean & Std Dev & Obs \\
\hline \multicolumn{10}{|l|}{ Health Insurance Variables } \\
\hline Premiums & 5,266 & 1,955 & 513,068 & 4,782 & 1,658 & 288,900 & 5,959 & 2,131 & 224,168 \\
\hline HI from Employer & 0.51 & 0.50 & 513,068 & 0.50 & 0.50 & 288,900 & 0.51 & 0.50 & 303,628 \\
\hline Any HI & 0.82 & 0.39 & 513,068 & 0.81 & 0.39 & 288,900 & 0.82 & 0.39 & 303,628 \\
\hline Employer Offers HI & 0.93 & 0.26 & 73,779 & 0.92 & 0.27 & 52,014 & 0.93 & 0.26 & 21,765 \\
\hline \multicolumn{10}{|l|}{ Labor Market Outcomes } \\
\hline Hours & 32.5 & 20.1 & 476,580 & 30.0 & 21.2 & 288,900 & 36.8 & 17.1 & 187,680 \\
\hline Wage and Salary Income (real) & 26,209 & 35,501 & 513,068 & 25,457 & 35,102 & 288,900 & 27,285 & 36,037 & 224,168 \\
\hline Part time (<30 hours per week) & 0.16 & 0.36 & 377,921 & 0.16 & 0.37 & 212,346 & 0.15 & 0.36 & 165,575 \\
\hline Employed & 0.80 & 0.40 & 476,580 & 0.74 & 0.44 & 288,900 & 0.90 & 0.29 & 187,680 \\
\hline \multicolumn{10}{|l|}{ Malpractice Payments (real per cap \$) } \\
\hline Total & 12.70 & 7.46 & 509,985 & 12.36 & 7.07 & 286,874 & 12.97 & 7.74 & 302,386 \\
\hline Internal Medicine & 7.38 & 4.49 & 509,985 & 7.15 & 4.25 & 286,874 & 7.57 & 4.71 & 302,386 \\
\hline Ob-Gyn & 1.75 & 1.33 & 493,610 & 1.66 & 1.27 & 278,897 & 1.82 & 1.35 & 292,813 \\
\hline Surgery & 3.33 & 1.97 & 509,985 & 3.30 & 1.90 & 286,874 & 3.35 & 1.97 & 302,386 \\
\hline \multicolumn{10}{|l|}{ Malpractice Payments (number per capita) } \\
\hline Total & 0.021 & 0.008 & 509,985 & 0.021 & 0.008 & 286,874 & 0.021 & 0.008 & 302,386 \\
\hline Internal Medicine & 0.094 & 0.043 & 509,985 & 0.095 & 0.042 & 286,874 & 0.091 & 0.043 & 302,386 \\
\hline Ob-Gyn & 0.033 & 0.016 & 493,610 & 0.033 & 0.015 & 278,897 & 0.033 & 0.015 & 292,813 \\
\hline Surgery & 0.029 & 0.011 & 509,985 & 0.029 & 0.011 & 286,874 & 0.030 & 0.011 & 302,386 \\
\hline
\end{tabular}

Notes: Individual-level observations from 1996-2002 Current Population Survey. Sample limited to those age 22-64.

Health insurance premiums from Kaiser/HRET survey (state-year data on premiums by policy type and employer size).

Malpractice payments from National Practitioner Data Bank.

Labor market outcomes and employer health insurance information from Current Population Survey (March and February). 
Table 2: Effect of Premiums on Labor Market Outcomes

\begin{tabular}{|c|c|c|c|c|c|c|c|c|c|c|c|c|c|c|}
\hline & \multicolumn{2}{|c|}{$\begin{array}{l}\text { Ln (Wage \& Salary } \\
\text { Income) }\end{array}$} & \multicolumn{2}{|c|}{ Employed } & \multicolumn{2}{|c|}{ Ln (Hours) } & \multicolumn{2}{|c|}{$\begin{array}{c}\text { Part Time } \\
\text { (if employed) }\end{array}$} & \multicolumn{2}{|c|}{$\begin{array}{c}\text { Have HI Through } \\
\text { Employer }\end{array}$} & \multicolumn{2}{|c|}{$\begin{array}{l}\text { Employee Share of } \\
\text { HI Premium }\end{array}$} & \multicolumn{2}{|c|}{$\begin{array}{c}\text { Ln (Employee } \\
\text { Contribution to HI) }\end{array}$} \\
\hline & OLS & IV & OLS & IV & OLS & IV & OLS & IV & OLS & IV & OLS & IV & OLS & IV \\
\hline & (1) & (2) & (3) & (4) & (5) & (6) & (7) & (8) & (9) & (10) & (11) & (12) & (13) & (14) \\
\hline \multicolumn{15}{|l|}{ Sample: All } \\
\hline Ln (HI Premium) & $\begin{array}{r}-0.033 \\
(.020)\end{array}$ & $\begin{array}{l}-0.128 \\
(.136)\end{array}$ & $\begin{array}{r}-0.004 \\
(.007)\end{array}$ & $\begin{array}{r}-0.155 \\
(.071)\end{array}$ & $\begin{array}{l}0.004 \\
(.005)\end{array}$ & $\begin{array}{r}-0.102 \\
(.054)\end{array}$ & $\begin{array}{l}0.005 \\
(.007)\end{array}$ & $\begin{array}{l}0.186 \\
(.061)\end{array}$ & $\begin{array}{r}-0.027 \\
(.013)\end{array}$ & $\begin{array}{r}-0.063 \\
(.092)\end{array}$ & $\begin{array}{r}-0.145 \\
(.031)\end{array}$ & $\begin{array}{r}-0.020 \\
(.103)\end{array}$ & $\begin{array}{l}0.397 \\
(.122)\end{array}$ & $\begin{array}{l}1.130 \\
(.419)\end{array}$ \\
\hline R-squared & 0.237 & 0.237 & 0.161 & 0.154 & 0.080 & 0.075 & 0.047 & 0.033 & 0.111 & 0.111 & 0.626 & 0.616 & 0.921 & 0.918 \\
\hline $\mathrm{N}$ & 346,524 & 346,524 & 447,883 & 447,883 & 368,230 & 368,230 & 328,952 & 328,952 & 447,883 & 447,883 & 368,230 & 368,230 & 368,230 & 368,230 \\
\hline Covariates and FEs & yes & yes & yes & yes & yes & yes & yes & yes & yes & yes & yes & yes & yes & yes \\
\hline
\end{tabular}

Notes:

Individual-level observations from 1996-2002 Current Population Survey. Sample limited to those age 22-64.

Health insurance premiums from Kaiser/HRET survey (state-year data on premiums by policy type and employer size).

Malpractice payments from National Practitioner Data Bank.

Labor market outcomes and employer health insurance information from Current Population Survey (March).

Part-time workers work less than 30 hours per week.

Covariates include race, age, age $\wedge 2$, age $\wedge 3$, marital status, education, gender, and health status.

Instruments include real dollar amount and number of medical malpractice payments per capita for different specialties (surgery, ob-gyn, internal medicine, and other) for current year

and previous year.

Premiums assigned based on state, year, family structure (and employer size for employed).

Regressions weighted by March CPS weights, and standard errors clustered at state level. 
Table 3: First Stage Regressions

\begin{tabular}{|c|c|c|c|}
\hline & \multicolumn{3}{|c|}{$\begin{array}{c}\text { Effect of Growth in } \\
\text { Malpractice Payments on } \\
\text { Health InsurancePremiums } \\
\text { (log-log specification) }\end{array}$} \\
\hline & (1) & (2) & (4) \\
\hline All Payments & $\begin{array}{c}0.011 \\
(.007)\end{array}$ & $\begin{array}{r}0.010 \\
(.005)\end{array}$ & \\
\hline Surgical Payments & & & $\begin{array}{r}0.014 \\
(.007)\end{array}$ \\
\hline Ob-Gyn Payments & & & $\begin{array}{r}-0.003 \\
(.004)\end{array}$ \\
\hline Internal Med Payments & & & $\begin{array}{l}0.006 \\
(.010)\end{array}$ \\
\hline Other Payments & & & $\begin{array}{r}-0.002 \\
(.001)\end{array}$ \\
\hline Number of Surg Pymts & & & $\begin{array}{r}-0.015 \\
(.012)\end{array}$ \\
\hline Number of Ob-Gyn Pymts & & & $\begin{array}{l}0.007 \\
(.007)\end{array}$ \\
\hline Number of Int Med Pymts & & & $\begin{array}{r}0.010 \\
(.019)\end{array}$ \\
\hline Number of Other Pymts & & & $\begin{array}{r}-0.003 \\
(.003)\end{array}$ \\
\hline F-test significance & 0.125 & 0.048 & 0.004 \\
\hline Covariates & no & yes & yes \\
\hline State and year effects & yes & yes & yes \\
\hline
\end{tabular}

Notes:

Individual-level observations from 1996-2002 Current Population Survey. Sample limited to those age 22-64.

Health insurance premiums from Kaiser/HRET survey (state-year data on premiums by policy type and employer size).

Malpractice payments from National Practitioner Data Bank. Covariates include race, age, age $\wedge 2$, age ${ }^{\wedge} 3$, marital status, education, gender, and health status.

Standard errors clustered at state level.

Growth of payments measured as change in real payments per capita or number of payments per capita. 


\section{Table 4: Differential Effects of Premium Increases}

Health Insurance Premiums Instrumented with Malpractice Payments

\begin{tabular}{|c|c|c|c|c|c|c|c|c|}
\hline & \multicolumn{3}{|c|}{ Ln (Wage \& Salary Income) } & \multicolumn{4}{|c|}{ Employer HI } & \multirow{2}{*}{$\begin{array}{c}\text { Employed } \\
\text { (8) }\end{array}$} \\
\hline & (1) & $(2)$ & (3) & (4) & (5) & (6) & (7) & \\
\hline Ln (HI Premium) & $\begin{array}{r}-0.114 \\
(0.196)\end{array}$ & $\begin{array}{r}-0.313 \\
(0.166)\end{array}$ & $\begin{array}{r}-0.195 \\
(0.134)\end{array}$ & $\begin{array}{r}-0.040 \\
(0.103)\end{array}$ & $\begin{array}{r}0.002 \\
(0.109)\end{array}$ & $\begin{array}{r}-0.102 \\
(0.100)\end{array}$ & $\begin{array}{r}-0.065 \\
(0.102)\end{array}$ & $\begin{array}{r}-0.079 \\
(0.068)\end{array}$ \\
\hline Ln (HI Prem) *Employer HI & $\begin{array}{l}-0.225 \\
(0.033)\end{array}$ & & & & & & & \\
\hline Ln (HI Prem) *Part Time & & $\begin{array}{r}0.103 \\
(0.052)\end{array}$ & & $\begin{array}{r}-0.021 \\
(0.024)\end{array}$ & & & & \\
\hline $\begin{array}{l}\text { Ln (HI Prem) *(Female, Married, \& } \\
\text { Healthy) }\end{array}$ & & & & & $\begin{array}{r}-0.107 \\
(0.028)\end{array}$ & & & \\
\hline $\begin{array}{l}\text { Ln (HI Prem) *Low Wage Hourly } \\
\text { Worker }\end{array}$ & & & & & & $\begin{array}{r}-0.094 \\
(0.030)\end{array}$ & & \\
\hline Ln (HI Prem) *Manufacturing & & & $\begin{array}{r}-0.134 \\
(0.033)\end{array}$ & & & & $\begin{array}{r}-0.020 \\
(0.035)\end{array}$ & $\begin{array}{r}-0.057 \\
(0.015)\end{array}$ \\
\hline Employer HI & $\begin{array}{r}2.510 \\
(0.289)\end{array}$ & & & & & & & \\
\hline Part Time & & $\begin{array}{r}-1.634 \\
(0.431)\end{array}$ & & $\begin{array}{l}-0.125 \\
(0.202)\end{array}$ & & & & \\
\hline Female, Married, \& Healthy & & & & & $\begin{array}{r}0.770 \\
(0.244)\end{array}$ & & & \\
\hline Low Wage Hourly Worker & & & & & & $\begin{array}{r}0.625 \\
(0.250)\end{array}$ & & \\
\hline Manufacturing & & & $\begin{array}{r}1.362 \\
(0.281)\end{array}$ & & & & $\begin{array}{r}0.356 \\
(0.296)\end{array}$ & $\begin{array}{l}0.502 \\
(.125)\end{array}$ \\
\hline R-squared & 0.33 & 0.32 & 0.25 & 0.12 & 0.08 & 0.07 & 0.08 & 0.03 \\
\hline $\mathrm{N}$ & 304,744 & 304,744 & 304,744 & 328,952 & 328,952 & 328,952 & 323,899 & 368,230 \\
\hline Sample & Employed & Employed & Employed & Employed & Employed & Employed & Employed & All \\
\hline
\end{tabular}

Notes:

Individual-level observations from 1996-2002 Current Population Survey. Sample limited to those age 22-64.

Health insurance premiums from Kaiser/HRET survey (state-year data on premiums by policy type and employer size)

Malpractice payments from National Practitioner Data Bank.

Labor market outcomes and employer health insurance information from Current Population Survey (March).

Part-time work defined as less than 30 hours per week. Low wage hourly workers defined as those paid less than $\$ 8 /$ hour. Healthy defined as self-reported

Instruments include real dollar amount and number of medical malpractice payments per capita for different specialties (surgery, ob-gyn, internal medicine,

Premiums assigned based on state, year, family structure (and employer size for employed). 


\section{Table 5: Health Insurance Offering}

Health Insurance Premiums Instrumented with Malpractice Payments

\begin{tabular}{lcc}
\hline \hline & \multicolumn{2}{c}{$\begin{array}{c}\text { Offered Employer Health Insurance } \\
\text { Among Employed }\end{array}$} \\
\cline { 2 - 3 } & \multicolumn{1}{c}{$(1)$} & \\
& & \\
Ln (HI Premium) & 0.082 & -0.381 \\
& $(.200)$ & $(.169)$ \\
N & & 10,754 \\
Sample & 69,120 & Hrly Workers \\
\hline
\end{tabular}

Notes:

Individual-level observations from Current Population Survey. Sample

limited to those age 22-64 included in both February and March

Supplements, 1997, 1999, 2001.

Health insurance premiums from Kaiser/HRET survey (state-year data on premiums by policy type and employer size).

Malpractice payments from National Practitioner Data Bank.

Labor market outcomes and employer health insurance information from

Current Population Survey (March and February).

Part-time work defined as less than 30 hours per week.

Low wage hourly workers defined as those paid less than $\$ 8 /$ hour.

Healthy defined as self-reported health excellent or very good.

Instruments include real dollar amount and number of medical malpractice payments per capita for different specialties (surgery, ob-gyn, internal medicine, and other) for current year and previous year.

Premiums assigned based on state, year, family structure (and employer size for employed). 
Table 6: Specification Checks

\begin{tabular}{|c|c|c|c|c|c|c|c|c|c|}
\hline \multirow[b]{3}{*}{ Sample: All } & Black & College & Female & Married & Good Health & \multirow{2}{*}{$\begin{array}{c}\text { Employer } \\
\text { Pension } \\
\text { (6) }\end{array}$} & \multicolumn{2}{|c|}{ Mortality Rates } & \multirow{2}{*}{$\begin{array}{c}\text { C-section } \\
\text { Rates } \\
(9)\end{array}$} \\
\hline & (1) & (2) & (3) & (4) & (5) & & (7) & (8) & \\
\hline & & & & & & & & & \\
\hline Ln (HI Premium) & $\begin{array}{r}-0.014 \\
(0.056)\end{array}$ & $\begin{array}{r}0.057 \\
(0.067)\end{array}$ & $\begin{array}{r}-0.015 \\
(0.047)\end{array}$ & $\begin{array}{r}-0.081 \\
(0.072)\end{array}$ & $\begin{array}{c}-0.097 \\
(0.090)\end{array}$ & $\begin{array}{r}0.122 \\
(0.120)\end{array}$ & $\begin{array}{r}0.001 \\
(0.002)\end{array}$ & $\begin{array}{r}0.0003 \\
(0.0004)\end{array}$ & $\begin{array}{r}-0.072 \\
(0.144)\end{array}$ \\
\hline R-squared & 0.097 & 0.076 & 0.002 & 0.003 & 0.108 & 0.077 & 0.990 & 0.091 & 0.984 \\
\hline $\mathrm{N}$ & 447,883 & 447,883 & 447,883 & 447,883 & 447,883 & 447,883 & 240 & 206 & 240 \\
\hline State and Year FEs & yes & yes & yes & yes & yes & yes & yes & yes & yes \\
\hline Sample & CPS Micro & CPS Micro & CPS Micro & CPS Micro & CPS Micro & CPS Micro & State-year & State-year & State-year \\
\hline
\end{tabular}

Notes:

Individual-level observations from 1996-2002 Current Population Survey. Sample limited to those age 22-64.

Health insurance premiums from Kaiser/HRET survey (state-year data on premiums by policy type and employer size).

Malpractice payments from National Practitioner Data Bank.

Labor market outcomes and employer health insurance information from Current Population Survey (March).

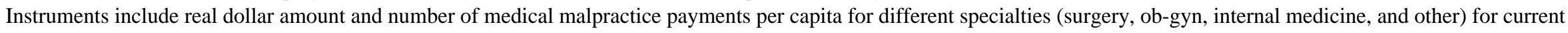
year and previous year.

Premiums assigned based on state, year, family structure (and employer size for employed).

Regressions weighted by March CPS weights, and standard errors clustered at state level.

Covariates include race, age, age $\wedge 2$, age $\wedge 3$, marital status, education, gender, and health status, excluding dependent variable. 
Table 7: Effects of 20 Percent Increase in Premiums

\begin{tabular}{lrr}
\hline \hline & Mean & Coefficient \\
\cline { 2 - 3 } & & Effect \\
Probability of being employed (percentage point) & $73 \%$ & -0.155 \\
Probability of working full time, conditional on working (percentage point) & $-3.1 \%$ \\
Average hours per week, conditional on working & -0.186 & -0.102 \\
Average annual income (insignificant) & $-3.7 \%$ \\
Average annual income, conditional on working and having employer HI & -0.8 \\
& -86.128 & -0.225 \\
\hline
\end{tabular}

